\title{
Labor Market Adjustment In High-Tech Industries: A Critical Review
}

Mr. Amlan Mitra, Economics, Purdue University Calumet Dr. Bhaskar J. Das, Economics, Purdue University Calumet

\begin{abstract}
Capitalist restructuring in the United States has been a key force in reshaping cities and regions in the late 1970s and 1980s. The emergence of high-tech industries and its impact on the level of employment, the quality of work, and the condition of labor is at the core of the social debate over the high-tech led economic development. Some researchers argue that high-tech industries have a positive effect on labor markets. Others seem to support the idea of a significant negative impact exercised by high-technologies on employment patterns and occupational composition. The purpose of this paper is to provide some insights on this debate by critically examining the relevant literature. We conclude that there is a need to inquire further into the labor market adjustment at the local level to unravel the inner complexities.
\end{abstract}

\section{Introduction}

In the last decade we have witnessed a process of economic restructuring linked to changes in advanced industrial societies affected by a changing international economic environment. Capitalist restructuring in the United States has been a key force in reshaping cities and regions in the late 1970s and 1980s. The emergence of high-tech industries and its impact on the level of employment, the quality of work, and the condition of labor, is at the core of the social debate over the high-tech led economic development.

There are both hopes and fears for the economy and for people when economic restructuring takes place. There is a hope when the diffusion of technological revolution throughout all sectors of activity, from the emergence of high-tech industries, leads to new innovation and growth (Rosenberg, 1976). There is a fear if the widespread use of labor-saving process oriented technologies will worsen unemployment, both functional and structural (U.S. Congress, 1984).

It is viewed by some researchers that when labor saving high technology emerges in the work process, there is a considerable reduction in working time per unit of output (Hunt \& Hunt, 1983; Maeda, 1980; Cockroft, 1980; Drennan, 1983; Roesner et al., 1985). However, the reduction in labor time can be offset by new demand for the products due to lower prices and improved quality resulting from improved technologies. In addition, enhanced competitiveness among firms may lead to much lowering of prices and thereby increasing demand and generating more employment to produce higher level of output.

There is a lot of debate over this above issue. Kaplinsky (1986) mentioned that there may be various interpretations depending on the levels of discourse one takes: process level, plant level, firm level, industry level, region level, sector level, national level, and international level.

Most of the research on high technology industries have revolved around various theoretical explanations of locational patterns of selected high technology industrial sectors and their influence on the dynamics of industrial organization and local labor market activities. It is evident, however, that these theories must be greatly extended in their analytical and substantive terms of reference before they can function as a satisfactory explanatory framework. Past studies have provided empirical support to some of these theoretical underpinnings. Among the few researchers on the subject of local labor market adjustment in high technology industries Scott, Storper, and Walker contributed to a 
great extent. Scott and Storper (1987) indicated in their research that there is a need to inquire further into the local labor market adjustment to unravel the inner complexities.

Against this theoretical background, the objective of this paper is to provide some insights on this debate by critically examining the relevant literature and discuss the significance of local labor market adjustment in high-tech industries.

\section{Implications Of Recent Literature}

High-tech industries may have a positive effect on labor markets in a number of ways: by stimulating production and employment in the capital goods sector; by increasing productivity; alleviating disputes over redistribution; and by extending productivity increases to the service sector (Lawrence, 1984). However, Castells (1988) observed that while the available empirical evidence does not seem to support the idea of a significant negative impact exercised by high-technologies on the aggregate level of employment in the U.S., there are a number of substantial new trends in the evolution of the occupational structure in these labor markets:

(1) A fast rate of growth of high-technology manufacturing and advance services-related jobs, yet accounting for only a small proportion of total new jobs, and an even lower share of overall aggregate employment.

(2) A bipolar occupational structure in high-technology manufacturing, as well as in manufacturing industries, fostered by intensive penetration by microelectronics-based process technologies. This bipolar structure is characterized by the juxtaposition of two main groups of workers: professionals, engineers, and technicians on the one hand, most of them being white and male; and low-skilled, low-paid direct manufacturing jobs, generally held by women and ethnic minorities.

(3) A massive increase in service jobs, which will account for about 75 percent of all new jobs in the period 1982-95. Most of these jobs will be in low skill, low-pay occupations, such as building custodians, cashiers, secretaries, waiters, general clerks, etc.

(4) A significant increase in the share of total employment taken by high-level occupations, such as professionals and technicians, from 16.3 percent in 1982 to 17.1 percent in 1995.

Also, if Rumberger and Levin's findings (1984) are confirmatory then it would seem that the process of restructuring leads to the simultaneous upgrading and downgrading of the occupational structure, although with changing emphasis in different industries and occupations. Kutsher (1985) analyzed that there was a statistical relationship between the current process of technological change and the specific profile of the occupational structure emerging in the U.S. Highly paid new technical and professional jobs are created in the high-tech industries due to increasing productivity and competition in the labor market. The free labor generated from the use of automation in both factories and offices are used by the expansionary service sector (Castells, 1989).

Against this background of a declining growth rate of the labor force, high-technology does not create unemployment by itself. But, when used to foster productivity and economic growth, it contributes to higher demand, investment, and output, ultimately expanding employment, mainly outside the high-technology sector of the economy. Yet high-technology does seem to contribute to an occupational structure characterized by polarization and segmentation of the labor force.

The new high-technology plays a major role in the reorganization of the labor process through cheapening labor and weakening union power. Although there are numerous evidences that new technologies do generate jobs, the number of jobs generated is not enough to compensate for the ones eliminated by adopting high technology. Markusen (1983) estimated that during the 1980s high-tech jobs would generate 3 million new jobs, while, their use would eliminate 25 million jobs. Yet Wayne's study (1984) argued that the current trend in U.S. showed that the dynamics of the economy due to high-tech, will generate new jobs outside high-tech activities in new sectors different from those being automated. According to Castells (1989), there may be new jobs, nonetheless, the fundamental feature in the employment structure is the mismatch between characteristics of jobs that disappear and those of newly created jobs. Bluestone and Harrison (1982) and Serrin (1983) found that while there has been an upgrading of professional and technical jobs in advanced services, the new unskilled jobs are found in low-paying services and down-graded manufacturing, where cheap labor is cheaper than automation. Other studies found similar trends in the new labor market (Hirschorn, 1984; Storper, 1982; Teitz, 1984; Walker, 1983).

B. O. hUallachain (1990) obtained three major sets of empirical results from his case studies. The most important and significant finding of his study is that high technology industries do not respond to the same set of locational determinants. Some industries respond to market strength whereas others are influenced by variation in labor force characteristics. There is, however, a deceleration in the rate of job growth or decline with increasing industry concentration or metropolitan size. 
The above empirical literature on high-tech industries and its impact on the labor market has several strands. Conflicting views have emerged about the implications of high-technology for productivity, employment, income redistribution, and re-organization of the labor process. Some experts say that the high-tech industries stimulate production in the capital goods sector, increase productivity, alleviate disputes over redistribution, and extend productivity to the service sector. These analysts assert that technological change is beneficial for all groups in our society, that the changes are more evolutionary than revolutionary in nature, and that high-technology ultimately creates more jobs than it eliminates. Other researchers fear that the widespread use of labor-saving process oriented technologies worsen unemployment (both functional and structural), adversely affects occupational composition, polarizes income, and cheapens labor with respect to capital.

Most of these findings are at the national level. Only a few researchers have conducted studies on some aspects of labor market in specific high-technology industries in major metropolitan areas. The impact of high-tech industries on the labor market at the city level may be different from the national level recognizing the non-uniqueness of locational characteristics. In addition, within cities labor market characteristics vary. Some industries may only respond to market strengths and influence the labor market in one way, whereas, others may be influenced by city size, labor force characteristics, etc. and have different impact on the labor market. Therefore, it is useful to conduct a comparative study within major metropolitan areas and find out how high-tech industries affect these local labor markets. This type of research will also help to compare the national trends to these cities.

\section{Conclusion}

Based on the hypotheses tested in earlier studies at the national level it may be useful to conduct future research testing some of those hypotheses at the local level. We suggest formulation of the following four major hypotheses:

a) Income Inequality Hypothesis: This states that there is a polarization of income of the labor force within a high-technology industry and also between hightechnology industries and other industries.

b) Relative Employment Hypothesis: It states that employment generated by high-tech industries are relatively few than other industries. However, the share of total employment taken by high-level occupations in high-tech industries has increased significantly relative to other industries. c) Skill Mismatch Hypothesis: This hypothesis, also known as "structural unemployment hypothesis," states that i) the number of new jobs generated by high- tech industries is not enough to compensate for the old ones eliminated by adopting high-technology; and ii) there is a mismatch between characteristics of jobs that disappear and those of newly created jobs in high-tech industries.

d) Capital-Labor Substitution/ Human Capital Complementarity: This states that high-tech industries play a major role in shifting capital-labor ratio and generating more human capital.

The following types of data will be needed to test the above hypotheses:

1. Total new jobs created in a city.

2. New jobs created in high-tech industries.

3. Total employment.

4. High-tech employment.

5. Types of jobs created in high tech industries.

6. Number of jobs with different degrees of skill.

7. Total earnings of high level occupations in high-tech industries.

8. Overall earnings of all occupations in high-tech industries.

9. Number of new jobs created.

10. Number of old jobs eliminated.

11. Number of jobs created in each profession.

12. Number of jobs eliminated in that profession.

13. Total labor and capital earnings in high-tech industries.

14. Rate of job growth in high-tech industries in a city.

15. Concentration of high-tech industries in a city and city size.

Depending on whether sufficiently disaggregated data will be available or not meaningful detailed conclusions can be made. The intent of this type of research should be to provide additional empirically based insight into the local labor markets in high-tech industries and compare the findings to the national trends. It will also help us understand any significant differences in labor market adjustment between cities.

\section{Suggestions For Future Research}

There is another consequence of high-technology besides the impact on local labor market. With the techno-economic restructuring adopted to supersede the structural crisis of the 1970 s, there is uneven development where economic sectors within a city have differential rate of investment. This phenomenon of uneven development may be clear and widely recognized, but it's causes and consequences are not. There is intersectoral differentiation within a city due to uneven development caused by the emergence of high-tech 
industries. Some industries literally die while others explode. There is increasing disparity between those sectors where disinvestment occurs and those where investment goes. Future research can add the spatial dimensions of industrial anatomy to explain how divergent locational needs of high-tech industries lead to uneven development in the cities.

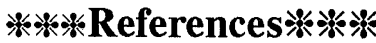

1. Bluestone, B. \& B. Harrison, The Deindustrialization of America: Plant Closings, Community Abandonment, and the Dismantling of Basic Industries, New York: Basic Books, 1982.

2. Castells, M., "High technology economic restructuring, and the urban-regional process in the United States," In High Technology, Space, and Society, ed., M. Castells, Sage, Beverly Hills, CA, pp. 11-40, 1985.

$3 . \longrightarrow$,High Technology and urban dynamics in the United States." In M. Dogan and J. Kasarda (eds.), The Metropolis Era, Vol. 1: A World of Giant Cities. Newbury Park, CA: Sage, pp. 85-110, 1988.

4. MA: Basil Blackwell, 1989.

5. Cockroft, D., "New Office Technology and Employment," International Law Review, Vol. 6, p. 119, Nov-Dec, 1980.

6. Drennan, M. P., "Implications of Computer and Telecommunications Technology for Less Skilled Service Employment Opportunities," Research Report to the U.S. Department of Labor, New York, Columbia University, 1983.

7. Hirschorn, L., Beyond Mechanization: Work and Technology in Post-Industrial Age, Cambridge, MA: MIT Press, 1983.

8. hUallachain, B. O., "The location of US manufacturing: some empirical evidence on recent geographical shifts," Environment and Planning A, Vol. 22, pp. 1205-1222, 1990.

9. Hunt, H. A. \& Hunt, T. L., Human Resource Implications of Robotics, Kalamazoo, MI, W. E. Upjohn Institute for Employment Research, 1983.

10. Kaplinsky, R., "Microelectronics and Employment Revisited: A Review," a report prepared for the International Labor Office, World Employment Program, Brighton, University of Sussex, Institute of Development Studies, 1986.

11. Kutscher, R. E., "Factors influencing the changing employment structure of the U.S.," Paper delivered at the Second International Conference of Progetto Milano, Milan, 25 January, 1985.

12. Lawrence, R. Z., "The Employment Effects of Information Technologies: An Optimistic View," Paper delivered at the OECD Conference on the Social Challenge of Information Technologies, Berlin, 2830 November, 1984.
13. Maeda, N., "A Fact-finding Study on the Impacts of Microelectronics on Employment," Microelectronics, Productivity and Employment, Paris, OECD, pp. 15580, 1980.

14. Markusen, A. R., "High Tech Jobs, Markets, and Economic Development Prospects: Evidence from California," Built Environment, Vol. 9, No. 1, pp. 1828, 1983.

15. Roesner, J. D. et al., The Impact of Office Automation on Clerical Employment, 1985-2000, Westport, Conn., Quorum, 1985.

16. Rosenberg, N., Perspectives on Technology, New York, Cambridge University Press, 1976.

17. Rumberger, R. W. \& H. M. Levin, "Forecasting the Impact of New Technologies on the Future Job Market," Research Report, Stanford, Stanford University School of Education, 1984.

18. Scott, A. J. \& M. Storper, "High Technology Industry and Economic Development: A Theoretical Critique and Reconstruction," International Social Science Review, Vol. 12, pp. 35-47, 1987.

19. Serrin, W., "'High Tech' Is No Jobs Panacea, Experts Say." New York Times, 18 September, I-1+, 1983.

20. Storper, M., "The Spatial Division of Labor: Technology, the Labor Process and the Location of Industries," Ph.D. Dissertation, University of California, Berkeley, 1982.

21. Storper, M. \& R. Walker, "The Theory of Labor and The Theory of Location," International Journal of Urban and Regional Research, Vol. 7, pp. 1-41, 1983.

22. Teitz, M., "The California Economy, Changing Structure and Policy Responses," In California Policy Choices, edited by J. J. Kirlin and D. R. Winkler, 2 Vols., Los Angeles: University of Southern California Press, 1984.

23. U.S.Congress, Computerized Manufacturing Automation: Employment, Education, and the Workplace, Office of Technology Assessment, Washington D.C., Government Printing Office, 1984.

24. Walker, P. C., "The Distribution of Skill and the Division of Labor, 1950-1978," Ph.D. Dissertation, University of Massachusetts, 1983.

25. Wayne, L., "America's Astounding Job Machine," New York Times, 17 June, III-1+, 1984. 